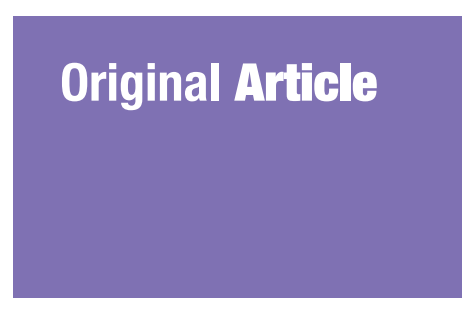

Submitted: 8 Sep 2020

Accepted: 12 Dec 2020

Online: 24 Feb 2021

\section{Analysis of $\mathrm{K}_{\mathrm{ATP}}$ Channels Opening Probability of Hippocampus Cells Treated with Kainic Acid}

\author{
Mohd Harizal SeNIK ${ }^{1,2}$, Izuddin Fahmy $\mathrm{ABU}^{3}$, Widad Fadhullah ${ }^{4}$
}

\author{
1 Department of Neurosciences, School of Medical Sciences, Universiti Sains \\ Malaysia, Kelantan, Malaysia \\ 2 School of Life Sciences, Medical School, Queen's Medical Centre, \\ University of Nottingham, Nottingham, United Kingdom \\ 3 Institute of Medical Science Technology, Universiti Kuala Lumpur, \\ Kuala Lumpur, Malaysia \\ 4 School of Industrial Technology, Universiti Sains Malaysia, Pulau Pinang, \\ Malaysia
}

To cite this article: Senik MH, Abu IF, Fadhullah W. Analysis of $\mathrm{K}_{\mathrm{ATP}}$ channels opening probability of hippocampus cells treated with Kainic acid. Malays $J$ Med Sci. 2021;28(1):15-26. https://doi.org/10.21315/ mjms2021.28.1.3

To link to this article: https://doi.org/10.21315/mjms2021.28.1.3

\title{
Abstract
}

Background: Kainic acid (KA)-induced seizures may be a valuable tool in the assessment of anti-epileptic drug efficacy in complex partial seizures. This study investigated the effects of KA on ATP-sensitive $K^{+}\left(K_{\mathrm{ATP}}\right)$ channels opening probability (NPo), which plays a crucial role in neuronal activities.

Methods: For the optimisation and validation protocol, $\beta$-cells were plated onto $35 \mathrm{~mm}$ plastic petri dishes and maintained in RPMI-1640 media supplemented with 10 mM glucose, $10 \%$ FCS and $25 \mathrm{mM}$ of N-2-hydroxyethylpiperazine-N-ethanesulfonic acid (HEPES). The treatment effects of $10 \mathrm{mM}$ glucose and $30 \mu \mathrm{M}$ fluoxetine on $K_{\mathrm{ATP}}$ channels NPo of $\beta$-cells were assessed via cell-attached patch-clamp recordings. For hippocampus cell experiments, hippocampi were harvested from day 17 of maternal Lister-hooded rat foetus, and then transferred to a $\mathrm{Ca}^{2+}$ and $\mathrm{Mg}^{2+}$-free HEPES-buffered Hank's salt solution (HHSS). The dissociated cells were cultured and plated onto a $25 \mathrm{~mm}$ round cover glasses coated with poly-d-lysine $(0.1 \mathrm{mg} / \mathrm{mL})$ in a petri dish. The $K_{\mathrm{ATP}}$ channels NPo of hippocampus cells when perfused with $1 \mathrm{mM}$ and $10 \mathrm{mM}$ of $\mathrm{KA}$ were determined.

Results: NPo of $\beta$-cells showed significant decreasing patterns $(P<0.001)$ when treated with $10 \mathrm{mM}$ glucose 0.048 (0.027) as well as $30 \mu \mathrm{M}$ fluoxetine $0.190(0.141)$ as compared to basal counterpart. In hippocampus cell experiment, a significant increase $(P<0.001)$ in mean NPo 2.148 (o.175) of neurons when applied with $1 \mathrm{mM}$ of KA as compared to basal was observed.

Conclusion: The two concentrations of KA used in the study exerted contrasting effects toward the mean of NPo. It is hypothesised that KA at lower concentration (1 mM) opens more $K_{\mathrm{ATP}}$ channels, leading to hyperpolarisation of the neurons, which may prevent neuronal hyper excitability. No effect was shown in $10 \mathrm{mM}$ KA treatment, suggesting that only lower than $10 \mathrm{mM}$ KA produced significant changes in $K_{\mathrm{ATP}}$ channels. This implies further validation of KA concentration to be used in the future.

Keywords: channel opening probability, epilepsy, hippocampus cells, Kainic acid, $K_{A T P}$ channels, pancreatic beta-cells, potassium channel 


\section{Introduction}

Epileptogenesis is the process of developing epilepsy, characterised by seizures that not only impair quality of life but can also lead to mortality (1). Epilepsy is normally caused by the imbalance of excitatory and inhibitory neurotransmitters in the brain, where glutamate is the predominant excitatory neurotransmitter in the central nervous system (2-4). Glutamatergic transmission plays a key role in the brain; however, overstimulation of glutamate receptors (GluRs) may lead to excitotoxicity $(5,6)$. Kainic acid (KA) is one of the excitatory amino acid that may stimulate GluRs (7). Experimentally, KA was frequently used to induce temporal lobe epilepsy (TLE) in animals (8-11) as a model to mimic human TLE. KA administration in rats can replicate three features of TLE by inducing initial injury, which affects the hippocampus and/or the temporal lobe (12), creating a latent period between the damage and causing the occurrence of spontaneous seizures $(9,10,13)$. Previous studies had shown that local administration (injected directly into the brain) or systemic administration (via intra-peritoneal injection) of $\mathrm{KA}$ in rodents triggered repetitive limbic seizures, status epilepticus (SE) $(8,14,15)$ and caused neuronal degeneration of the selected population of neurons in the brain (16).

Four different classes of $\mathrm{K}^{+}$channels have been identified: i) voltage-dependent $\mathrm{K}^{+}$channels $\left(\mathrm{K}_{\mathrm{V}}\right)$; ii) $\mathrm{Ca}^{2+}$-activated $\mathrm{K}^{+}\left(\mathrm{K}_{\mathrm{Ca}}\right)$ channels; iii) ATP-sensitive $\mathrm{K}^{+}\left(\mathrm{K}_{\mathrm{ATP}}\right)$ channels and iv) inward rectifier $\mathrm{K}^{+}\left(\mathrm{K}_{\mathrm{ir}}\right)$ channels (17, 18). However, $K_{\text {ATP }}$ channels have been placed under the $\mathrm{K}_{\mathrm{ir}}$ super family of $\mathrm{K}^{+}$channels as it conducts weak inward rectifier potassium current $(19,20) . \mathrm{K}^{+}$channels are the most dominant ion conductive pathways in electrically excitable cells and regulate neuronal excitability by controlling the firing frequency of the action potentials $(20,21)$. The opening of the $\mathrm{K}^{+}$ channels hyperpolarise the cell by causing an efflux of $\mathrm{K}^{+}$ions. Subsequently, this condition is followed by the closure of voltage-dependent $\mathrm{Ca}^{2+}$ channels, with the consequent reduction in $\mathrm{Ca}^{2+}$ entry and vasodilatation $(22,23)$. On the other hand, the closure of $\mathrm{K}^{+}$channels causes membrane depolarisation and vasoconstriction (23-25). Thus, in the presence of a physiological or pharmacological agent that alters membrane potential, for instance, the $\mathrm{K}_{\mathrm{ATP}}$ channel openers cromakalim and pinacidil, may cause a significant change in blood vasolidation (22, 26, 27).

$\mathrm{K}_{\mathrm{ATP}}$ channels are ubiquitously present in cells, such as myocytes, pancreatic beta ( $\beta$ )-cells, and neurons $(20,28) . K_{\mathrm{ATP}}$ channels comprise of four pore-forming subunits $\left(\mathrm{K}_{\mathrm{ir}} 6.1\right.$ or $\mathrm{K}_{\mathrm{ir}} 6.2$ encoded by KCNJ8 and KCNJ11, respectively) and four regulatory sulfonylurea receptors (SUR) ATP-binding cassettes subunits (subfamily C: SUR1, SUR2A or SUR2B) (20). $K_{\text {ATP }}$ channels have been implicated in models of tissue injury, including the heart and brain (29). For example, a mutation in $\mathrm{K}_{\mathrm{ir}} 6.2$ results in a syndrome of developmental delay, infantile diabetes, and epilepsy $(30,31)$. The association of $\mathrm{K}_{\mathrm{ir}} 6.2$ channels and epilepsy has been previously described to be mainly caused by KCNJ11 mutation-related subtypes as demonstrated in diabetes with epilepsy as a co-morbidity (31-33). In diabetic conditions, $K_{\text {ATP }}$ channels in the $\beta$-cells of the pancreas exert an antihyperglycaemic effect by stimulating insulin secretion due to their closure in response to increasing plasma glucose concentration (34). Sulfonylureas are used in the treatment of non-insulin-dependent diabetes mellitus as oral hypoglycaemic agents by closing the $\mathrm{K}_{\text {ATP }}$ channels. The binding of sulfonylurea to the SUR induces closure of the channels and results in membrane depolarisation of the pancreatic $\beta$-cells, which in turn stimulates the secretion of insulin (35).

$\mathrm{K}_{\mathrm{ATP}}$ channels have been reported to demonstrate a significant role in neuroprotection and treating epileptic disorders in diabetic hyperglycaemia (36) and neuronal excitability in metabolic stress $(19,29,37)$. This mechanism initiates a more excitable state, which implies that an increase in extracellular glucose and intracellular ATP decreases $K_{\text {ATP }}$ channels (36). Apart from regulating neuronal excitability, neuronal $\mathrm{K}_{\mathrm{ATP}}$ channels also play an essential role in spontaneous firing in various neurons, including cholinergic basal forebrain neurons, expiratory neurons, entorhinal layer three cortical neurons, substantia nigra neurons, and thalamocortical neurons. Activation of $\mathrm{K}_{\text {ATP }}$ channels have also been shown to be neuroprotective in both focal and global ischemia as evident in in vivo models as well as in vitro experiments. These studies suggest that the effects are mediated at least in part by neuronal $\mathrm{K}_{\mathrm{ATP}}$ channels (20). $\mathrm{K}_{\mathrm{ATP}}$ channels were demonstrated to regulate the release of neurotransmitters and are involved in the 
protection against glutamate excitotoxicity in in vivo and cultured hippocampal neurons (28). $\mathrm{K}_{\text {AтP }}$ channels are activated by $\mathrm{Mg}$-ADP and blocked by ATP; these channel characteristics allow the cells to couple cellular metabolic state (ATP/ADP ratio) to electrical activity of the cell membrane $(20,38)$. In a way, the connection between the level of electrical activity and intracellular ATP concentration may suggest that $\mathrm{K}_{\text {АтP }}$ channel through its regulation of neuronal excitability may also serve for a potential antiepileptic mechanism (36).

Since $\mathrm{K}_{\mathrm{ATP}}$ channels are essentially implicated in neuronal activities such as neurotransmission, it is postulated that they play a fundamental role in the underlying process of direct or indirect neuronal hyper excitability. Consequently, this resulting epilepsy may lead to excitotoxic cell death. Therefore, this study aimed to provide preliminary $\mathrm{K}_{\text {ATP }}$ profiling of hippocampus cells treated with KA.

\section{Methods}

In this study, $\beta$-cells were used to optimise and validate the methods. $K_{\text {ATP }}$ channels activity of $\beta$-cell-line was investigated using a single channel patch-clamp technique in the cellattached configuration. Hippocampus cells were later used after $\beta$-cell validation and optimisation using the same protocol.

Considering the important role of pancreatic $K_{\text {ATP }}$ channels in regulating the secretion of insulin, this study investigated $\mathrm{K}_{\text {ATP }}$ channel activity in the presence of glucose and fluoxetine. Fluoxetine is a Food and Drug Administration (FDA)-approved antidepressant belonging to selective serotonin reuptake inhibitors (SSRI) class and used for the treatment of major depressive disorder, obsessive-compulsive disorder, bulimia nervosa and panic disorder. This antidepressant drug has been previously reported to interfere with blood glucose levels in rodents $(39,40)$, presumably by the interaction of $\mathrm{K}_{\mathrm{ATP}}$ channels to modulate channel activity.

\section{Preparation of $\beta$-cells (Optimising and Validating Purposes)}

$\beta$-cells were plated onto $35 \mathrm{~mm}$ plastic petri dishes (Nunc). Cells were cultured and maintained in RPMI-1640 media supplemented with $10 \mathrm{mM}$ glucose, 10\% FCS and $25 \mathrm{mM}$ HEPES. The petri dishes were then kept in humidified air $/ 5 \% \mathrm{CO}_{2}$ at normal body temperature $\left(37^{\circ} \mathrm{C}\right)$. The concentration of $10 \mathrm{mM}$ glucose was chosen to mimic the physiological blood glucose concentration within the range of $5 \mathrm{mM}$ to $8 \mathrm{mM}$ in subjects possessing a healthy metabolism and $11 \mathrm{mM}$ in diabetes patients after glucose exposure (41).

\section{Preparation of Hippocampus Cells}

All procedures were carried out in accordance with the Animals (Scientific Procedures) Act 1986, UK and have been approved by the UK Home Office (project license 40/3283 and personal license 40/10438). Maternal Lister-hooded rats at embryonic day 17 were anaesthetised with $\mathrm{CO}_{2}$ and sacrificed by decapitation to collect the foetuses (42). Hippocampi were harvested and transferred to a $\mathrm{Ca}^{2+}$ and $\mathrm{Mg}^{2+}$-free HEPES-buffered Hank's salt solution (HHSS), $\mathrm{pH}$ 7.45. Trituration was performed to dissociate the cells, which then were pelleted and re-suspended in Dulbecco's Modified Eagle's Media (DMEM) without glutamine and supplemented with 10\% foetal bovine serum (FBS), penicillin $(100 \mathrm{U} / \mathrm{mL})$ and streptomycin $(100 \mu \mathrm{g} / \mathrm{mL})$. The dissociated cells were then plated onto a $25 \mathrm{~mm}$ round cover glasses coated with poly-d-lysine $(0.1 \mathrm{mg} / \mathrm{mL})$ at a density of 50000 cells/well and washed with distilled water. The resulting neuron cells were cultured in DMEM containing 10\% FBS and penicillin/streptomycin for $24 \mathrm{~h}$ in a humidified atmosphere with $10 \% \mathrm{CO}_{2}$ and $90 \%$ air $(\mathrm{pH} 7.4)$ at $37{ }^{\circ} \mathrm{C}$. The cells were fed every 7 days by replacing $70 \%$ of the media with DMEM supplemented with 10\% horse serum and penicillin/streptomycin. The cells used in the above protocol were cultured without mitotic inhibitors for a minimum of 12 days $(42,43)$. The cells were ready to use on day 14 . Hippocampus cell culture images for cell-attached experiments at day 1,7 and 14 are shown in Figure 1.

\section{Solutions}

In the $\beta$-cells attached patch experiments for the measurement of $\mathrm{K}_{\mathrm{ATP}}$ current; the cells were pre-incubated prior to use in a sugar-free Hank's solution for $20 \mathrm{~min}-30 \mathrm{~min}$ at $37^{\circ} \mathrm{C}$. Experiments were performed in a high $\mathrm{K}^{+}$ HEPES-buffered Hanks' salt solution (HHSS) containing (in mM) $138 \mathrm{NaCl}, 4.2 \mathrm{NaHCO}_{3}$, $1.2 \mathrm{NaH}_{2} \mathrm{PO}_{4}, 5.6 \mathrm{KCl}, 1.2 \mathrm{MgCl}_{2}, 2.6 \mathrm{CaCl}_{2}, 10$ HEPES ( $\mathrm{pH} 7.4$ with $\mathrm{NaOH}$ ) as adapted from Smith et al. (44). To study the effect of glucose and fluoxetine on $\beta$-cell for the optimisation 
A

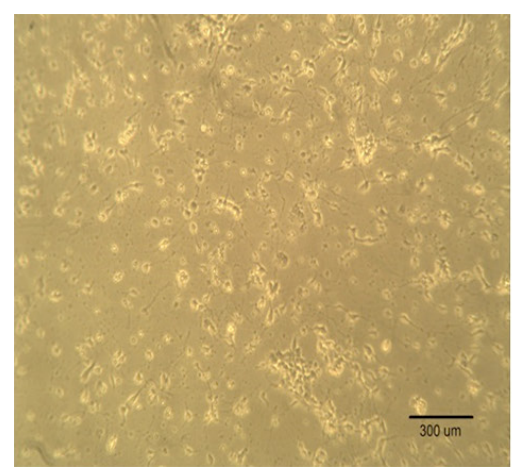

B

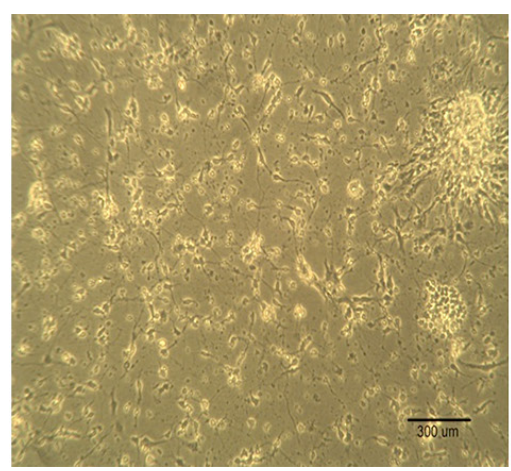

C

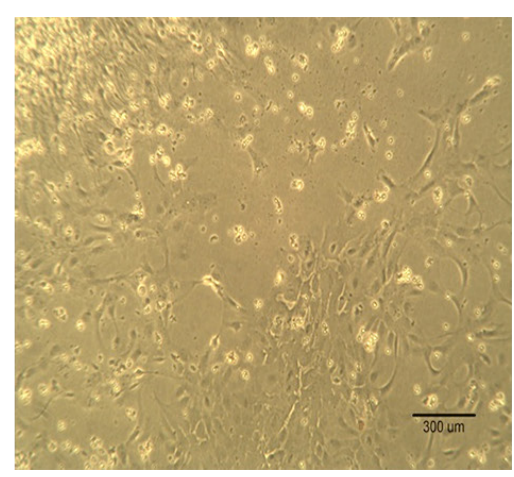

Figure 1. Hippocampus cell culture for cell-attached experiments at A. day 1 B. day 7 and C. day 14

and validation protocol, $10 \mathrm{mM}$ glucose and 30 $\mu \mathrm{M}$ fluoxetine was added to a high potassium depolarising (HiK) solution in two different beakers, respectively.

To study KA-treated hippocampus cells, two different concentrations of $\mathrm{KA}(1 \mathrm{mM}$ and $10 \mathrm{mM}$ ) were added separately to HHSS solution that contained i) $20 \mathrm{mM}$ HEPES; ii) $137 \mathrm{mM}$ $\mathrm{NaCI}$; iii) $1.3 \mathrm{mM} \mathrm{CaCl}$; iv) $0.4 \mathrm{mM} \mathrm{MgSO}_{4}$; v) $0.5 \mathrm{mM} \mathrm{MgCI}_{2}$; vi) $5.0 \mathrm{mM} \mathrm{KCI}$; vii) $0.4 \mathrm{mM}$ $\mathrm{KH}_{2} \mathrm{PO}_{4}$; viii) $0.6 \mathrm{mM} \mathrm{Na} \mathrm{HPO}_{4}$; ix) $3.0 \mathrm{mM}$ $\mathrm{NaHCO}_{3}$ and x) $5.6 \mathrm{mM}$ glucose.

For cell-attached patch-clamp recording, the pipette solution consisting of the followings (in $\mathrm{mM}$ ): i) $140 \mathrm{KCl}$; ii) $2.6 \mathrm{CaCl}_{2}$; iii) $1.2 \mathrm{MgCl}$ and iv) HEPES (pH 7.4) was prepared.

\section{Cell-Attached Patch-Clamp Recordings}

Borosilicate glass capillary pipettes (GC15OTF-15; Harvard, United Kingdom) pulled with a 2-stage vertical putter (Narishige PP83, Japan) were used for the patch-clamp recordings. Bubble number 7 was used to determine the diameter of the pipette tip. Sylgard silicone elastomer (Dow Corning Corp, Michigan, USA) was applied below the pipette tips and subsequently fire-polished before the use to avoid electrical noise. The pipettes were filled with a HiK solution using a micro-syringe. Any bubbles from the tip were removed with extra care. The suitable standard pipette resistances for use were between 2.5 $\mathrm{M} \Omega$ and $5 \mathrm{M} \Omega$.

Prior to the patching process, the $\beta$ - and hippocampus cells were washed using Hank's solution. Only cells that were evidently round and morphologically distinct were patched. The patch was sealed by pressing the pipette against the cell surface before applying light suction to the inside of the pipette. The position of hippocampus cell and micropipette for the cell- attached experiment is demonstrated in Figure 2. Only patches forming seals in the giga-ohm range were recorded.

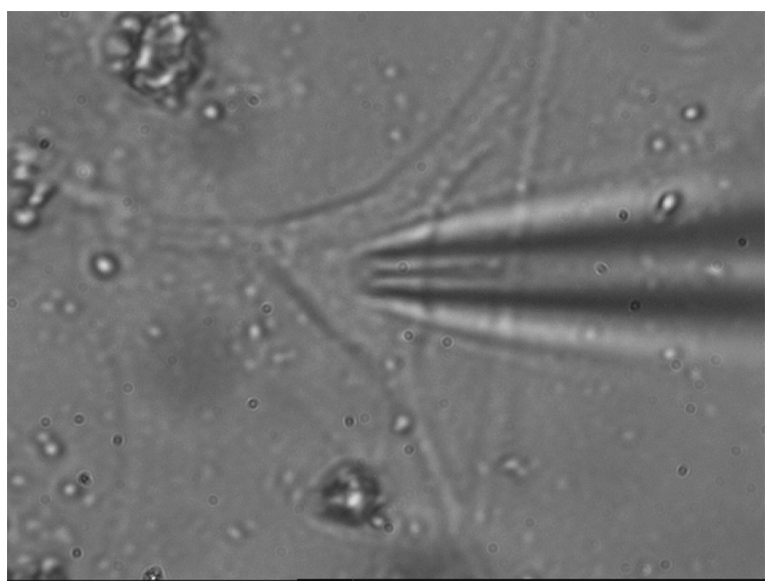

Figure 2. Position of hippocampus cell and micropipette for cell-attached experiment

The cell-attached recordings were made using an Axopatch patch-clamp amplifier (Molecular Devices Inc., Sunnyvale, CA, USA). Single-channel currents were filtered at $2 \mathrm{kHz}$ prior to digitisation at $10 \mathrm{kHz}$ using Clampfit 10.3 (Molecular Devices Inc., Sunnyvale, CA, USA) connected to Axopatch-1D patch-clamp amplifier (Axon instruments, San Jose, CA, USA). Singlechannel currents were recorded at a pipette potential of $\mathrm{o} \mathrm{mV}$, at the resting membrane potential (44). All procedures were conducted within room temperature of $21^{\circ} \mathrm{C}-23^{\circ} \mathrm{C}$.

The channel activities were measured by the open probability (NPo). All NPo values were calculated from $3 \mathrm{~min}$ of a single-channel recording. Data from each patch membrane served as the control. NPo after seal and 
perfusion by Hank's solution served as the basal record and was compared with NPo of treatment as adapted from Smith et al. (44).

\section{Statistical Analysis}

One-way ANOVA was performed followed by Bonferroni's multiple comparison tests using Graphpad Prism 8.o to determine the statistical significance between glucose, fluoxetine and basal in the $\beta$-cell experiment and between two concentrations of $\mathrm{KA}(1 \mathrm{mM}$ and $10 \mathrm{mM})$ and basal in the hippocampus cell experiment. $P$-values of less than 0.001 were considered statistically significant. The data were presented as mean (SEM), where $n$ is the number of cellattachment experiments and each ones were from a different petri dish.

\section{Results}

\section{Optimisation and Validation Experiment Using $\beta$-Cells}

All individual experiments $(n=5)$ showed similar patterns with lower $\mathrm{K}_{\mathrm{ATP}}$ channels NPo in $\beta$-cells when applied with $10 \mathrm{mM}$ glucose as well as $30 \mu \mathrm{M}$ fluoxetine and being normalised to basal record (HIK solution) as the control (Figure 3A). Figure $3 \mathrm{~B}$, shows a significant decrease of NPo of $K_{\text {ATP }}$ channels activity when applied with glucose 0.048 (0.027) and fluoxetine 0.190 (0.141) compared to basal $\left(F_{(2,12)}=38.26, P<0.001\right.$; one-way ANOVA $)$.

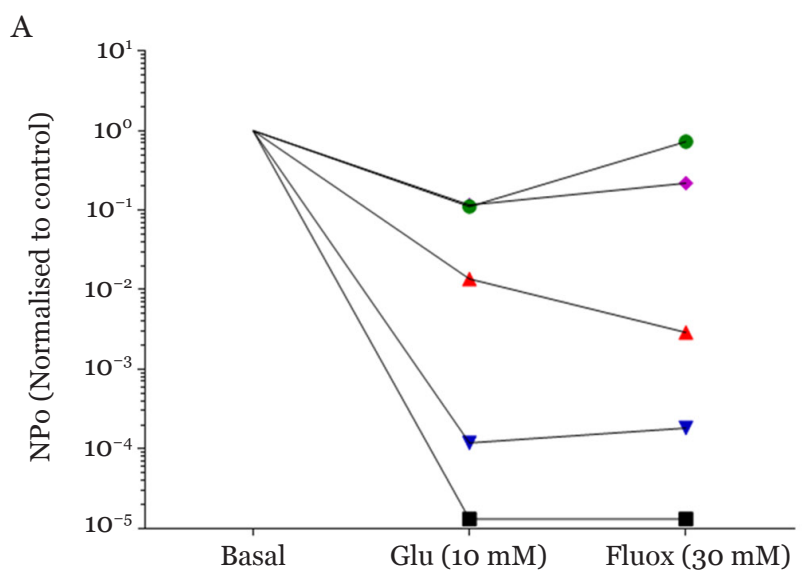

The single-channel $\mathrm{K}_{\text {ATP }}$ blockage through the addition of $10 \mathrm{mM}$ glucose was demonstrated by the drop of mean NPo, in agreement with previous findings by Tringham et al. (45). The reason for this phenomenon is due to the concurrent surge in cell metabolism and increased ATP/ADP ratio, which inhibits the $\mathrm{K}_{\mathrm{ATP}}$ channels.

\section{Hippocampus Cell-Attached Experiment}

As this observation is dependent on cell conditions, therefore, it was important to use the cell-attached configuration to retain the KA metabolism of the hippocampus cells intact. In order to characterise the $\mathrm{K}_{\mathrm{ATP}}$ singlechannel activities in cell-attached, the channel currents were made and visually evaluated. Representative results of the effects of $1 \mathrm{mM}$ and $10 \mathrm{mM} \mathrm{KA}$ on $\mathrm{K}_{\mathrm{ATP}}$ single-channel activities are depicted in Figure 4. Figure 4A shows the single-channel records under unmodified condition of HHSS bath solution while Figure $4 \mathrm{~B}$, displays the reactivation of the $\mathrm{K}_{\mathrm{ATP}}$ channels after the addition of $1 \mathrm{mM} \mathrm{KA}$ in HHSS solution. Figure $4 \mathrm{C}$, demonstrates the subsequent bath application of $10 \mathrm{mM} \mathrm{KA}$ in HHSS solution.

As shown in Figure $5 \mathrm{~A}$, it was observed that the two concentrations of KA used in this study gave two different effects on the NPo of $\mathrm{K}_{\text {АTP }}$ channels. All individual experiments $(n=4)$ demonstrated that $1 \mathrm{mM} \mathrm{KA}$ increased the NPo compared to basal. The ratio of NPo

B

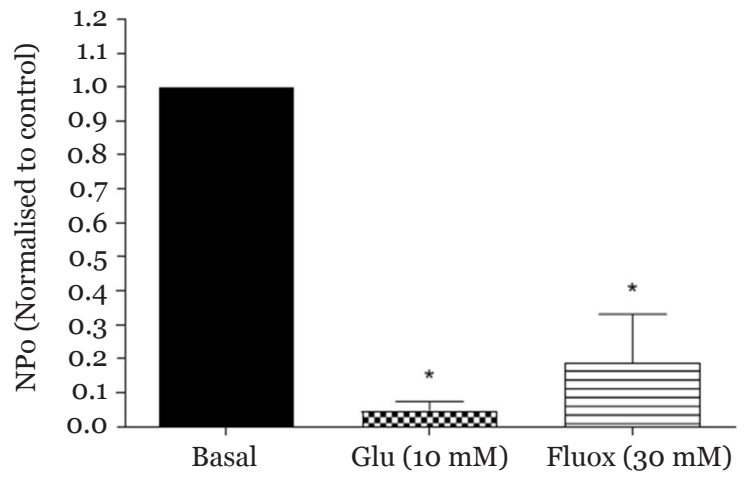

Figure 3. Effects of glucose and fluoxetine on single $\mathrm{K}_{\mathrm{ATP}}$ channels opening probability (NPo) in 3 min perfusion $(n=5)$. A. Individual experiment (represented by each line) showed reduced NPo of $\mathrm{K}_{\mathrm{ATP}}$ channels when applied with $10 \mathrm{mM}$ of glucose and $30 \mu \mathrm{M}$ fluoxetine compared to basal counterpart (HiK solution). B. Mean NPo ratio of $\mathrm{K}_{\mathrm{ATP}}$ channels activity when perfused with glucose and fluoxetine in comparison to basal. NPo of glucose and fluoxetine are normalised to basal, respectively

${ }^{*}$ Statistically significant difference with comparison to basal, $P<0.001$ using one-way ANOVA followed by Bonferroni's multiple comparisons test 




Figure 4. Representative records of $\mathrm{K}_{\mathrm{ATP}}$ activity measured in a hippocampus cell-attached patch with a pipette potential of $+70 \mathrm{mV}$. The images show $\mathrm{K}_{\mathrm{ATP}}$ single-channel currents during $\mathbf{A}$. perfusion of unmodified HHSS solution (basal), B. in the presence of $1 \mathrm{mM}$ of KA in HHSS, and $\mathbf{C}$. in the presence of $10 \mathrm{mM}$ of KA in HHSS

when perfused with $1 \mathrm{mM}$ KA was significantly increased 2.148 (o.1748) as compared to basal (HHSS solution) $\left(F_{(2,9)}=42.72, P<0.001\right)$ (Figure $5 \mathrm{~B}$ ). In contrast, the difference of NPo ratio between $\mathrm{KA}$ at a higher concentration (10 $\mathrm{mM}$ ) and basal was not statistically significant. It is hypothesised that $1 \mathrm{mM} \mathrm{KA}$ opens more $\mathrm{K}_{\mathrm{ATP}}$ channels and lead to the hyper polarisation of the neurons.

\section{Discussion}

In our study utilising pancreatic $\beta$-cell, $\mathrm{K}_{\text {ATP }}$ channels were shown to be blocked by $10 \mathrm{mM}$ glucose which is consistent with early documented reports on the effects of glucose on $\mathrm{K}_{\mathrm{ATP}}$ channel kinetics (46-48). This is due to the concomitant elevation in cell metabolism and the increase of ATP/ADP ratio, which inhibits the $\mathrm{K}_{\mathrm{ATP}}$ channels. Studies have shown that when plasma glucose level rises in pancreatic $\beta$-cells, the concentration of ATP increases the glucose level, which results in closure of $\mathrm{K}_{\mathrm{ATP}}$ channels $(49,50)$. $\mathrm{K}_{\mathrm{ATP}}$ channels closure in the plasma membrane allows the cells to depolarise, subsequently triggering calcium entry and insulin release (51-53).

In this experiment, $30 \mu \mathrm{M}$ fluoxetine also caused blockage of $\mathrm{K}_{\mathrm{ATP}}$ channels as shown by the decrease of NPo. Fluoxetine is currently an important drug for the treatment of major depression and obsessive-compulsive disorder. Previous and recent studies have reported that depression is a critical problem in diabetic patients (54-57). It has also been documented that the fluoxetine elevates blood glucose and reduces plasma insulin levels $(40,54,58-60)$. In the present study, the effect of glucose and fluoxetine was examined in the context of the insulin-secretory pathway in the pancreatic 
A

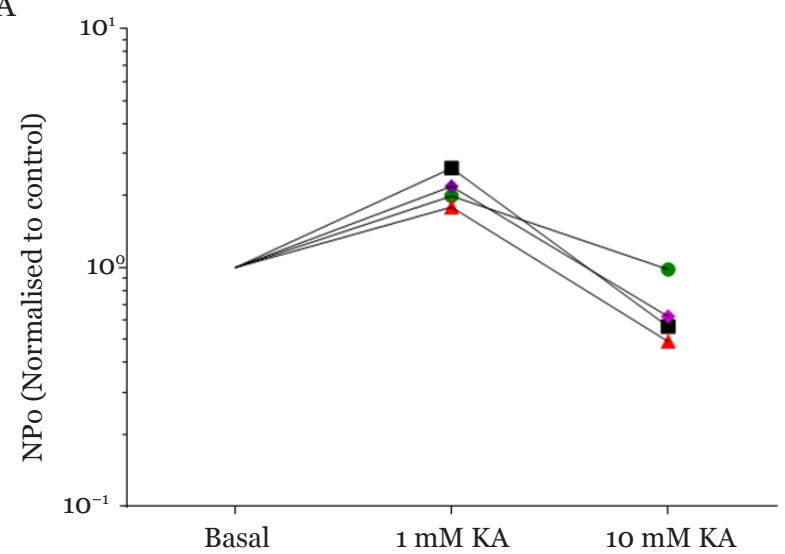

B

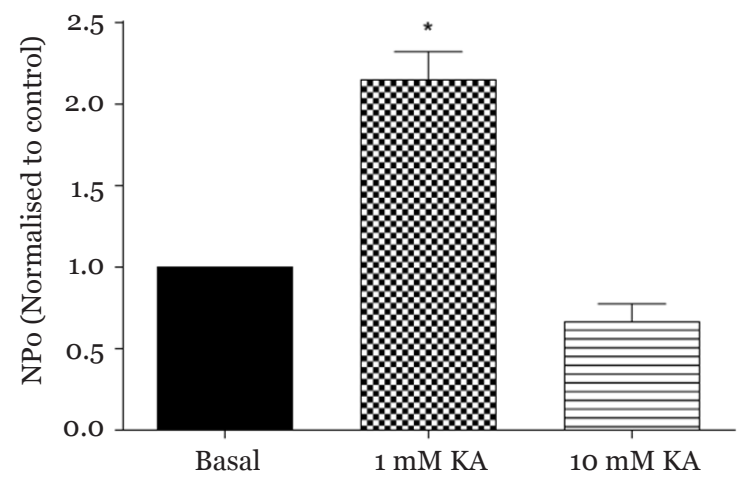

Figure 5. Effects of KA in two different concentrations ( $1 \mathrm{mM}$ and $10 \mathrm{mM})$ on $\mathrm{K}_{\mathrm{ATP}}$ channels activities in $3 \mathrm{~min}$ perfusion $(n=4)$. A. Effects of KA on $\mathrm{K}_{\mathrm{ATP}}$ channels activities (NPo) during 3 min interval as shown by individual experiments. B. Effects of KA on NPo ratio of $\mathrm{K}_{\mathrm{ATP}}$ channels activities in comparison to basal. NPo of $1 \mathrm{mM}$ and $10 \mathrm{mM}$ of KA are normalised to basal (HHSS solution), respectively

${ }^{*}$ Statistically significant difference in comparison to basal, $P<0.001$ using one-way ANOVA followed by Bonferroni’s multiple comparisons test

$\beta$-cells. They were also used to optimise and validate the method and to compare the $\mathrm{K}_{\mathrm{ATP}}$ profile.

The hippocampus is among the most vulnerable region towards KA-induced neuronal death $(61,62)$. KA induces continuous depolarisation and high intracellular $\mathrm{Ca}^{2+}$ entry, which potentiates the release and action of endogenous excitatory amino acids, activation of caspases, and nitric oxide production. These actions initiate excitotoxic cell death by necrosis, apoptosis, or both $(63-67)$. In this preliminary study, the findings demonstrated two varied effects from two different KA concentrations (1 $\mathrm{mM}$ and $10 \mathrm{mM}$ ). Lower concentration of KA $(1 \mathrm{mM})$ significantly increased NPo of $\mathrm{K}_{\mathrm{ATP}}$ channel of neurons during the $3 \mathrm{~min}$ acute perfusion that may generally cause neuronal hyper polarisation. $\mathrm{K}_{\mathrm{ATP}}$ openers mimic some of the neuroprotective effects of preconditioning, and in contrast, $\mathrm{K}_{\text {АTP }}$ blockers were used to reverse these effects (61). The mechanism involved suggests that activation of $\mathrm{K}_{\mathrm{ATP}}$ channels through adenosine receptors may act as an early step of ischemic-cerebral preconditioning (20, $68,69) . \mathrm{K}_{\text {ATP }}$ channels are regulated by the ATP/ ADP ratio in a way that a drop of this ratio will activate these channels. Following their opening, the efflux of $\mathrm{K}^{+}$will induce a hyper polarisation and decreases the neuronal excitability. $K_{\mathrm{ATP}}$ channels also control neurotransmitter release by regulating neuronal excitability $(38) . \mathrm{K}_{\mathrm{ATP}}$ channels may down regulate glutamate release $(28,70)$, and their over expression has beneficial effects in epilepsy $(38,71)$ and schizophrenia (72).

The $\mathrm{K}_{\mathrm{ATP}}$ channels in the hippocampus are thought to possess neuroprotective roles; cellular stress will activate these channels causing a transient membrane hyper polarisation with a consequent decrease of energy demand. Thus, rendering sufficient protection to the metabolically compromised cells (38). The $\mathrm{K}_{\text {АтP }}$ channels are coupled to the intracellular energy supply; when ATP levels are high, $\mathrm{K}_{\mathrm{ATP}}$ channels are closed, whereas during prolonged action potential firing $K_{\text {ATP }}$ channels will eventually contribute to resetting $(31,73)$. Seizure-like activity in hippocampal slices may be induced by $\mathrm{Mg}^{2+}$-free solution accompanied by ATP decrease and activation of $\mathrm{K}_{\text {ATP }}$ channels. Increased ATP consumption may contribute to excitotoxicity (74). In our case, $1 \mathrm{mM}$ of KA resulted in increased patterns of NPo which may cause hyper polarisation in hippocampus cells. By acting via membrane hyper polarisation and preventing propagation of the excitatory postsynaptic current, this mechanism may protect neurons from potentially excitotoxic insults (28). Simulations by Krishnan and Bazhenov (75) proposed significant effects of sodium accumulation in termination of seizures where, $\mathrm{K}_{\mathrm{ATP}}$ channels would close the loop: $\mathrm{GluR} \rightarrow \mathrm{Na}^{2+} \rightarrow \mathrm{Na}^{2+} / \mathrm{K}^{+}$-ATPase $\rightarrow$ ATP/ADP. 


\section{Conclusion}

This study showed contrasting effects of NPo between pancreatic $\beta$-cells and hippocampus cells. In the presence of glucose and fluoxetine, NPo of $K_{\text {ATP }}$ channels in $\beta$-cells decreased, while hippocampus cells treated with $1 \mathrm{mM}$ of KA showed increased NPo of $\mathrm{K}_{\text {ATP }}$ channels. Despite the small sample size, this study provided important preliminary information towards reaching a concrete conclusion on the effects of $\mathrm{KA}$ towards $\mathrm{K}_{\mathrm{ATP}}$ channels activities in hippocampus cells. As this study unexpectedly saw a wide contrasting effect in $\mathrm{K}_{\mathrm{ATP}}$ profiling between the two KA concentrations, future studies are needed with a wider range of concentrations.

\section{Acknowledgements}

The authors would like to thank Dr Paul Smith from Queen's Medical Centre, University of Nottingham, United Kingdom for the technical support and the Ministry of Higher Education, Malaysia for the financial support.

\section{Conflict of Interest}

None.

\section{Funds}

The Ministry of Higher Education PhD scholarship and Universiti Kuala Lumpur Short Term Research Grant (str18048).

\section{Authors' Contributions}

Conception and design: MHS

Analysis and interpretation of the data: MHS

Drafting of the article: MHS, WF

Critical revision of the article for important intellectual content: IFA

Final approval of the article: MHS

\section{Correspondence}

Dr Mohd Harizal Senik

$\mathrm{PhD}$ (University of Nottingham)

Department of Neurosciences,

School of Medical Sciences,

Universiti Sains Malaysia,

16150 Kubang Kerian, Kelantan, Malaysia.

Tel: +6097676439

Fax: +6097673833

E-mail: mharizalsenik@usm.my

\section{References}

1. Baruah J, Vasudevan A, Köhling R. Vascular integrity and signaling determining brain development, network excitability, and epileptogenesis. Front Physiol. 2020;10:1583. https://doi.org/10.3389/fphys.2019.01583

2. Fonnum F. Glutamate: a neurotransmitter in mammalian brain. $J$ Neurochem. 1984;42(1): 1-11. https://doi.org/10.1111/j.1471-4159.1984. tbog689.x

3. Barker-Haliski M, White HS. Glutamatergic mechanisms associated with seizures and epilepsy. Cold Spring Harb Perspect Med. 2015;5(8):a022863. https://doi.org/10.1101/ cshperspect.a022863

4. Hanada T. Ionotropic glutamate receptors in epilepsy: a review focusing on AMPA and NMDA receptors. Biomolecules. 2020;10(3):464. https://doi.org/10.339o/biom10030464

5. Olney JW, Gubareff TD. Glutamate neurotoxicity and Huntington's chorea. Nature. 1978;271(5645):557-559. https://doi .org/10.1038/271557ao

6. Crupi R, Impellizzeri D, Cuzzocrea S. Role of metabotropic glutamate receptors in neurological disorders. Front Mol Neurosci. 2019;12:20. https://doi.org/10.3389/fnmol.2019.00020

7. Mohandass A, Surenkhuu B, Covington K, Baskaran P, Lehmann TE, Thyagarajan B. Kainic acid activates TRP1 via a Phospholipase $\mathrm{C} / \mathrm{PIP} 2$-dependent mechanism in vitro. ACS Chem Neurosci. 2020;11(19):2999-3007. https://doi.org/10.1021/acschemneuro.oc00297 
8. Leite JP, Bortolotto ZA, Cavalheiro EA. Spontaneous recurrent seizures in rats: an experimental model of partial epilepsy. Neurosci Biobehav Rev. 1990;14(4):511-517. https://doi.org/10.1016/So149-7634(05)80076-4

9. Sharma AK, Searfoss GH, Reams RY, Jordan WH, Snyder PW, Chiang AY, et al. Kainic acid-induced F-344 rat model of mesial temporal lobe epilepsy: gene expression and canonical pathways. Toxicol Pathol. 2009;37(6):776-789. https://doi.org/10 $.1177 / 0192623309344202$

10. Kandratavicius L, Balista PA, Lopes-Aguiar C, Ruggiero RN, Umeoka EH, Garcia-Cairasco, N et al. Animal models of epilepsy: use and limitations. Neuropsychiatr Dis Treat. 2014;10:1693-1705. https://doi.org/10.2147/NDT.S50371

11. Lévesque M, Avoli M, Bernard C. Animal models of temporal lobe epilepsy following systemic chemoconvulsant administration. $J$ Neurosci Methods. 2016;260:45-52. https://doi.org/10 $.1016 /$ j.jneumeth.2015.03.009

12. Bouilleret V, Ridoux V, Depaulis A, Marescaux C, Nehlig A, Le Gal La Salle G. Recurrent seizures and hippocampal sclerosis following intrahippocampal kainate injection in adult mice: electroencephalography, histopathology and synaptic reorganization similar to mesial temporal lobe epilepsy. Neuroscience. 1999;89:717-729. https://doi.org/10.1016/So306-4522(98)00401-1

13. Bertoglio D, Amhaoul $\mathrm{H}$, van Eetveldt A, Houbrechts R, Van De Vijver S, Ali I, et al. Kainic acid-induced post-status epilepticus models of temporal lobe epilepsy with diverging seizure phenotype and neuropathology. Front Neurol. 2017;8:588. https://doi.org/10.3389/ fneur.2017.00588

14. Furtado MA, Braga GK, Oliveira JA, Del Vecchio F, Garcia-Cairasco N. Behavioral, morphological and electroencephalographic evaluation of seizures induced by intrahippocampal microinjection of pilocarpine. Epilepsia. 2002;43(Suppl 5):37-39. https://doi.org/10 $.1046 / j .1528-1157 \cdot 43 . s .5 \cdot 41 . x$

15. Lévesque $\mathrm{M}$, Avoli $\mathrm{M}$. The kainic acid model of temporal lobe epilepsy. Neurosci Biobehav Rev. 2013;37(10 Pt 2):2887-2899. https://doi.org/10.1016/j.neubiorev.2013.10.011
16. Mohd Sairazi NS, Sirajudeen KN, Asari MA, Muzaimi M, Mummedy S, Sulaiman SA. Kainic acid-induced excitotoxicity experimental model: protective merits of natural products and plant extracts. $J$ Evid Based Complementary Altern Med. 2015;2015:972623. https://doi.org/10.1155/2015/972623

17. Jackson WF. Potassium channels in the peripheral microcirculation. Microcirculation. 2005;12(1):113-127. https://doi.org/10.1080/ 10739680590896072

18. Dookeran KA, Auer P. The emerging role of twopore domain potassium channels in breast cancer. J Glob Epidemiol Environ Health. 2017;1(1):2736. https://doi.org/10.29199/2637-7144/GEEH $-101014$

19. Seino S, Miki T. Physiological and pathophysiological roles of ATP-sensitive $\mathrm{K}+$ channels. Prog Biophys $\mathrm{Mol}$ Biol. 2003;81(2):133-176. https://doi.org/10.1016/ s0079-6107(02)00053-6

20. Szeto V, Chen N, Sun H, Feng Z. The role of $K_{\text {ATP }}$ channels in cerebral ischemic stroke and diabetes. Acta Pharmacol Sin. 2018;39(5):683-694. https://doi.org/10.1038/aps.2018.10

21. Diao Y, Tian Y, Han S, Zhang N, Li J, Yin Y. Current insight into the role of voltage-gated potassiumion channel 7 (Kv7) channels: an emerging therapy target against epilepsy. Neuropsychiatry. 2017;7(1):26-31.

22. Yanagisawa T, Yamagishi $\mathrm{T}$, Okada $\mathrm{Y}$. Hyperpolarization induced by $\mathrm{K}^{+}$channel openers inhibits $\mathrm{Ca}^{2+}$ influx and $\mathrm{Ca}^{2+}$ release in coronary artery. Cardiovasc Drugs Ther. 1993;7(S3):565574. https://doi.org/10.1007/bfoo877622

23. Jackson WF. Potassium channels in regulation of vascular smooth muscle contraction and growth. Adv Pharmacol. 2017;78:89-144. https://doi.org/10.1016/bs.apha.2016.07.001

24. Post JM, Weir EK, Archer SL, Hume JR. Redox regulation of $\mathrm{K}^{+}$channels and hypoxic pulmonary vasoconstriction. In: Weir EK, Hume JR, Reeves $\mathrm{JT}$, editors. Ion flux in pulmonary vascular control. Boston, MA: Springer; 1993. pp 189-204. https://doi.org/10.1007/978-1-4615-2397-0_15 
25. Kirschstein T, Rehberg M, Bajorat R, Tokay T, Porath K, Köhling R. High $\mathrm{K}^{+}$-induced contraction requires depolarization-induced $\mathrm{Ca}^{2+}$ release from internal stores in rat gut smooth muscle. Acta Pharmacol Sin. 2009;30(8):11231131. https://doi.org/10.1038/aps.2009.98

26. Baker EH. Ion channels and the control of blood pressure. Br J Clin Pharmacol. 2000;49(3):185198. https://doi.org/10.1046/j.1365-2125.2000 .00159.x

27. Syed AU, Koide M, Brayden JE, Wellman GC. Tonic regulation of middle meningeal artery diameter by ATP-sensitive potassium channels. $J$ Cereb Blood Flow Metab, 2019;39(4):670-679. https://doi.org/10.1177/ 0271678X17749392

28. Shukry M, Kamal T, Ali R, Farrag F, Almadaly E, Saleh AA, et al. Pinacidil and levamisole prevent glutamate-induced death of hippocampal neuronal cells through reducing ROS production. Neurol Res. 2015;37(10):916-923. https://doi.org/10.1179/1743132815y.0000000077

29. Kim DY, Abdelwahab MG, Lee SH, O’Neill D, Thompson RJ, Duff HJ, et al. Ketones prevent oxidative impairment of hippocampal synaptic integrity through $\mathrm{K}_{\mathrm{ATP}}$ channels. PLoS One. 2015;10(4):e0119316. https://doi.org/10.1371/ journal.pone.0119316

30. Hattersley AT, Ashcroft FM. Activating mutations in $\mathrm{K}_{\mathrm{ir}} 6.2$ and neonatal diabetes: New clinical syndromes, new scientific insights, and new therapy. Diabetes. 2005;54(9): 2503-2513. https://doi.org/10.2337/diabetes.54.9.2503

31. Köhling R, Wolfart J. Potassium channels in epilepsy. Cold Spring Harb Perspect Med. 2016;6(5):a022871. https://doi.org/10.1101/ cshperspect.a022871

32. Slingerland AS, Hattersley AT. Mutations in the $K_{\text {ir }} 6.2$ subunit of the $K_{\text {ATP }}$ channel and permanent neonatal diabetes: New insights and new treatment. Annals of Medicine. 2005;37(3):186-195. https://doi.org/10.1080/ 07853890510007287

33. Shah P, Demirbilek H, Hussain K. Persistent hyperinsulinaemic hypoglycaemia in infancy. Semin Pediatr Surg. 2014:23(2):76-82. https://doi.org/10.1053/j.sempedsurg.2014.03.005
34. Maechler P. Mitochondria as the conductor of metabolic signals for insulin exocytosis in pancreatic beta-cells. Cell Mol Life Sci. 2002;59(11):1803-1818. https://doi.org/10 $.1007 /$ plooo 12507

35. Zhou M, He HJ, Tanaka O, Sekiguchi M, Kawahara K, Abe H. Localization of the ATPsensitive $\mathrm{K}^{+}$channel regulatory subunits SUR2A and SUR2B in the rat brain. Neurosci Res. 2012;74(2):91-105. https://doi.org/10.1016/ j.neures.2012.08.005

36. Huang CW. The potential role of ATP-sensitive potassium channels in treating epileptic disorders. In: Afawi Z, editor. Clinical and genetic aspects of epilepsy. London: IntechOpen; 2011. https://doi.org/10.5772/20709

37. Liss B, Roeper J. A role for neuronal $\mathrm{K}_{\mathrm{ATP}}$ channels in metabolic control of the seizure gate. Trends Pharmacol Sci. 2001;22(12):599-601. https://doi.org/10.1016/So165-6147(00)01861-7

38. Yamada K, Inagaki N. Neuroprotection by $\mathrm{K}_{\mathrm{ATP}}$ channels. J Mol Cell Cardiol. 2005;38(6):945949. https://doi.org/10.1016/j.yjmcc.2004.11.020

39. Erenmemisoglu A, Ozdogan UK, Saraymen R, Tutus A. Effect of some antidepressants on glycaemia and insulin levels of normoglycaemic and alloxan-induced hyperglycaemic mice. $J$ Pharm Pharmacol. 1999;51(6):741-743. https://doi.org/10.1211/0022357991772899

40. Gomez R, Huber J, Tombini G, Barros HMT Acute effect of different antidepressants on glycemia in diabetic and non-diabetic rats. Braz $J$ Med Biol Res. 2001;34(1):57-64. https://doi.org/10 $.1590 /$ s0100-879x2001000100007

41. Rubin RR, Ma Y, Marrero DG, Peyrot M, Barrett-Connor EL, Kahn SE, et al. Elevated depression symptoms, antidepressant medicine use, and risk of developing diabetes during the diabetes prevention program. Diabetes Care. 2008;31(3):420-426. https://doi.org/10.2337/ dco7-1827

42. Chen BS, Wu SN. Functional role of the activity of ATP-sensitive potassium channels in electrical behavior of hippocampal neurons: experimental and theoretical studies. $J$ Theor Biol. 2011;272:16-25. https://doi.org/10.1016/ j.jtbi.2010.12.003 
43. Sokal DM, Mason R, Parker TL. Multi-neuronal recordings reveal a differential effect of thapsigargin on bicuculline- or gabazine-induced epileptiform excitability in rat hippocampal neuronal networks. Neuropharmacology. 2000;39(12):2408-2417. https://doi.org/10 .1016/Soo28-3908(00)00095-2

44. Smith PA, Williams BA, Ashcroft FM. Block of ATP-sensitive $\mathrm{K}^{+}$channels in isolated mouse pancreatic $\beta$-cells by 2,3-butanedione monoxime. $\mathrm{Br} J$ Pharmacol. 1994;112(1):143-149. https://doi.org/10.1111/j $.1476-5381.1994 . t b 13044 . x$

45. Tringham E, Powell KL, Cain SM, Kuplast K, Mezeyova J, Weerapura M, et al. T-type calcium channel blockers that attenuate thalamic burst firing and suppress absence seizures. Sci Transl Med. 2012;4(121):121ra119. https://doi.org/10.1126/scitranslmed.3003120

46. Rorsman P, Trube G. Glucose dependent $\mathrm{K}^{+}-$ channels in pancreatic $\beta$-cells are regulated by intracellular ATP. Pflügers Archiv: Eur J Physiol. 1985;405(4):305-309. https://doi.org/10.1007/ BFoo595682

47. Ashcroft S, Harrison D. The glucose-sensitive potassium channel in rat pancreatic beta-cells is inhibited by intracellular ATP. J Physiol-London. 1985;369:101.

48. Ashcroft FM, Ashcroft SJ, Harrison DE. Properties of single potassium channels modulated by glucose in rat pancreatic beta-cells. $J \quad$ Physiol. 1988;400:501-527. https://doi.org/10.1113/jphysiol.1988.spo17134

49. Cook DL, Hales N. Intracellular ATP directly blocks $\mathrm{K}^{+}$channels in pancreatic $\beta$-cells. Nature. 1984;311(5983):271-273. https://doi.org/10 $.1038 / 311271 \mathrm{ao}$

50. Kakei M, Kelly RP, Ashcroft SJH, Ashcroft FM. The ATP-sensitivity of $\mathrm{K}^{+}$channels in rat pancreatic B-cells is modulated by ADP. FEBS Letters. 1986;208(1):63-66. https://doi.org/10 .1016/0014-5793(86)81533-2

51. Henquin JC. Triggering and amplifying pathways of regulation of insulin secretion by glucose. Diabetes. 2000;49(11):1751-1760. https://doi .org/10.2337/diabetes.49.11.1751
52. Miki T, Liss B, Minami K, Shiuchi T, Saraya A, Kashima Y, et al. ATP-sensitive $\mathrm{K}^{+}$channels in the hypothalamus are essential for the maintenance of glucose homeostasis. Nat Neurosci. 2001;4(5):507-512. https://doi.org/ $10.1038 / 87455$

53. Ashcroft FM, Rorsman $P$. $K_{\text {ATP }}$ channels and islet hormone secretion: new insights and controversies. Nat Rev Endocrinol. 2013;9(11):660-669. https://doi.org/10.1038/ nrendo.2013.166

54. Goodnick PJ, Henry HJ, Buki MVM. Treatment of depression in patients with diabetes mellitus. $J$ Clin Psychiatry. 1995;56:128-136.

55. Goodnick PJ. Practical considerations in the treatment of depression in the diabetic patient. Prim Psychiatry. 1997;4: 37-40.

56. Lustman PJ, Freedland KE, Griffith LS, Clouse RE. Fluoxetine for depression in diabetes: a randomized double-blind placebo-controlled trial. Diabetes Care. 2000;23(5):618-623. https://doi.org/10.2337/diacare.23.5.618

57. Zanoveli JM, de Morais H, da Silva Dias IC, Schreiber AK, de Souza CP, da Cunha JM. Depression associated with diabetes: from pathophysiology to treatment. Curr Diabetes Rev. 2016;12(3):165-178. https://doi.org/10.2174/ 1573399811666150515125349

58. Kaplan SM, Mass JW, Pixley JM, Ross WD. Use of imipramine in diabetics: effects on glycosuria and blood sugar levels. JAMA. 1960;174(5):511-517. https://doi.org/10.1001/ jama.1960.63030050009013

59. Katz LM, Fochtman LF, Pato MT. Clomipramine, fluoxetine and glucose control. Ann Clin Psychiatry. 1991;3(4):271-274.

6o. El Dakhakhny M, Hekmat A, El-Latif A. Different effects of the antidepressant drugs: imipramine, maprotiline and bupropion on insulin secretion from mouse pancreatic islets. Arzneimittelforschung. 1996;46(7):667-669. 
61. Plamondon H, Blondeau N, Heurteaux C, Lazdunski M. Mutually protective actions of Kainic acid epileptic preconditioning and sublethal global ischemia on hippocampal neuronal death: involvement of adenosine A1 receptors and KATP channels. $J$ Cereb Blood Flow Metab. 1999;19(12):1296-1308. https://doi.org/10.1097/00004647-19991200000002

62. Zheng $\mathrm{XY}$, Zhang HL, Luo Q, Zhu J. Kainic acid-induced neurodegenerative model: potentials and limitations. $J$ Biomed Biotechnol. 2011;2011:457079. https://doi.org/10.1155/2011/ 457079

63. Siesjö BK, Wieloch T. Cerebral metabolism in ischaemia: neurochemical basis for therapy. Br J Anaesth. 1985;57(1):47-62. https://doi .org/10.1093/bja/57.1.47

64. Choi D. Glutamate neurotoxicity and diseases of the nervous system. Neuron. 1988;1(8):623-634. https://doi.org/10.1016/o896-6273(88)90162-6

65. Huang YY, Li XC, Kandel ER. cAMP contributes to mossy fiber LTP by initiating both a covalently mediated early phase and macromolecular synthesis-dependent late phase. Cell. 1994;79(1):69-79. https://doi.org/10.1016/0092 $-8674(94) 90401-4$

66. Namura S, Zhu J, Fink K, Endres M, Srinivasan A, Tomaselli KJ et al. Activation and cleavage of caspase-3 in apoptosis induced by experimental cerebral ischemia. $J$ Neurosci. 1998;18(10):3659-3668. https://doi.org/10 $.1523 / J N E U R O S C I .18-10-03659.1998$

67. Mohd Sairazi NS, Sirajudeen K, Asari MA, Mummedy S, Muzaimi M, Sulaiman SA. Effect of Tualang honey against KA-induced oxidative stress and neurodegeneration in the cortex of rats. BMC Complement Altern Med. 2017;17(1):31. https://doi.org/10.1186/s12906-016-1534-x

68. Abele AE, Miller RJ. Potassium channel activators abolish excitotoxicity in cultured hippocampal pyramidal neurons. Neurosci Lett. 1990;115(2-3):195-200. https://doi.org/10 $.1016 / 0304-3940(90) 90454-\mathrm{h}$
69. Heurteaux C, Lauritzen I, Widmann C, Lazdunski M. Essential role of adenosine, adenosine A1 receptors, and ATP-sensitive $\mathrm{K}^{+}$channels in cerebral ischemic preconditioning. Proc Natl Acad Sci. 1995;92(10):4666-4670. https://doi .org/10.1073/pnas.92.10.4666

70. Soundarapandian MM, Zhong X, Peng L, Wu D, Lu Y. Role of KATP channels in protection against neuronal excitatory insults. $J$ Neurochem. 2007;103(5):1721-1729. https://doi.org/10.1111/ j.1471-4159.2007.04963.x

71. Fogle KJ, Hertzler JI, Shon JH, Palladino MJ. The ATP-sensitive $\mathrm{K}$ channel is seizure protective and required for effective dietary therapy in a model of mitochondrial encephalomyopathy. $J \quad$ Neurogenet. 2016;30(3-4):247-258. https://doi.org/10.1080/01677063.2016.1252765

72. Hernández-Sánchez C, Basile AS, Fedorova I, Arima H, Stannard B, Fernandez AM, et al. Mice transgenically overexpressing sulfonylurea receptor 1 in forebrain resist seizure induction and excitotoxic neuron death. Proc Natl Acad Sci. 2001;98(6):3549-3554. https://doi.org/10 $.1073 /$ pnas.051012898

73. Isomoto $\mathrm{S}$, Kondo $\mathrm{C}$, Kurachi $\mathrm{Y}$. Inwardly rectifying potassium channels: their molecular heterogeneity and function. Jpn $J$ Physiol. 1997;47(1):11-39. https://doi.org/10.2170/ jjphysiol.47.11

74. Erecinska M, Cherian S, Silver IA. Brain development and susceptibility to damage; ion levels and movements. Neural Dev. 2005;69:139-186. https://doi.org/10.1016/ soo70-2153(05)69006-0

75. Krishnan GP, Bazhenov M. Ionic dynamics mediate spontaneous termination of seizures and postictal depression state. $J$ Neurosci. 2011;31(24):8870-8882. https://doi.org/10 $.1523 /$ jneurosci.6200-10.2011 